\title{
LITERATURĂ
}

\author{
ALUNIŢA COFAN \\ alunitzacofan@gmail.com \\ Institutul de teorie și critică literară G. Călinescu, Bucureşti
}

\section{CAZUL URMUZ DIN PERSPECTIVA ESTETICII GROTESCULUI}

\begin{abstract}
Aluniţa Cofan, Cazul Urmuz din perspectiva esteticii grotescului [The Urmuz's literary case from the perspective of aesthetics of grotesque], Studia Romanica Posnaniensia, Adam Mickiewicz University Press, Poznań, vol. XLI/2: 2014, pp. 59-71. ISBN 978-83-232-2703-8. ISSN 0137-2475. eISSN 2084-4158. DOI: 10.7169/strop2014.412.005

We are trying in the following phenomenological approach to go on with our description concerning the grotesque in Romanian literature. In the first part of our work, we will make a short and diachronic review of the most important writings belonging to Romanian authors from the XIX-th century till the first decade of the XX-th century. It is then when a mysterious and shy Romanian writer, called URMUZ, gave birth to a few but influential literary pages of the absurd and the grotesque. In the second part of our work we will analyze the distinguishing traits of his ten works of prose through the mirror of the grotesque. This ignored Romanian writer was baptized "a new Alfred Jarry", although he never had heard about this French author and never read about Ubu. The hidden influence of Urmuz unknowingly modernized the concept of literarity.
\end{abstract}

Keywords: the Urmuz's case, the rhetoric of grotesque, Romanian literature, Romanian authors from early XX-th century, Alfred Jarry

\section{MIC PREAMBUL DESPRE ESTETICA URMUZIANĂ}

Felul în care Urmuz şi-a conceput puţinele scrieri se încadrează în noile prefaceri ale conceptului de literaritate determinate de fenomenul de criză manifestat în literatura secolului XX. Scriitorul însuși a conştientizat natura inovatoare a scrierilor sale, dar a avut mari îndoieli privitoare la viabilitatea formulei literare propuse. Intuiţia lui artistică 1-a ghidat în acţiunea riscantă a transformării gustului epocii. Mișcările tectonice din câmpul conceptului de literaritate au fost prevestite de anumite curente literare (romantismul, simbolismul), dar, mai ales, de anumiţi poeţi de la sfârşitul secolului al XIX-lea, precum Rimbaud, Lautréamont şi Mallarmé. Între dezordinea programată a lui Rimbaud (dérèglement de tous les sens), violentele expresii maldororiene şi austeritatea spiritualistă a poetului După-amiezii unui faun (L'après-midi d'un 
faune), calea spre revoluționarea literaturii era deschisă. Li se alătură acestora și unul dintre cei mai radicali scriitori pe calea revoluționării artei literare, și anume teatrul patafizician de marionete al lui Jarry. El a fost premergător pentru numeroase tendinţe literare ale secolului al XX-lea, printre care putem enumera avangardismul, absurdul şi expresionismul (Crohmălniceanu, 1978: 31, 44).

$\mathrm{Nu}$ se ştie dacă Urmuz a preferat anumite modele literare în detrimentul altora. De fapt, nu se cunosc prea bine modelele literare care ar fi putut contribui la fasonarea conştiinţei sale artistice, fiindcă, fapt arhicunoscut, a lăsat prea puţine mărturii directe în urma sa, iar celelalte, indirecte (de pildă, anecdotele povestite de G. Ciprian, medalionul lui T. Arghezi, sau cele câteva referiri ale lui Saşa Pană), îi alcătuiesc legenda. Pe urmă, o altă ciudăţenie a acestui scriitor este că reflecţiile şi cugetările din caietele sale manuscrise sunt de o plată banalitate și cumințenie, asemenea celor ale lui Lautréamont, ce contrazic total şi radical spiritul scrierilor date tiparului (Crohmălniceanu, 1972: 571).

Datele biografice, în special cele transmise de contemporanii săi (Arghezi, Saşa Pană, G. Ciprian) nu ne ajută prea mult, dacă am dori să cercetăm poietica operei și a semnificațiilor sale în din punct de vedere teoretic. Tot ceea ce putem reconstitui despre gândirea urmuziană asupra literarităţii ori a esteticii sale, se bazează pe cele zece texte rămase de la el, începând cu ,păţaniile" lui Stamate şi încheindu-se cu pasiunea „legumicolă” a lui Saraffof. Originalitatea sa, deşi a dat naştere la emuli, n-a putut fi copiată, în ciuda influenţelor exercitate. Genul de scriitură pe care-l propune Urmuz şi din care vom regăsi anumite caracteristici atât în literatura absurdului (cf. mărturisirile lui Eugen Ionescu - Balotă, 1971: 378), cât și în textualismul și postmodernimul de mai târziu, este devastator pentru cumințenia literaturii tradiționale.

Urmuz este primul scriitor artifex ludum din literatura română, iar textele lui sunt nişte artefacte literare ludice, în stilul pictural prea bine cunoscut din tablourile lui Picasso şi Braque sau al read-made-urilor lui Marcel Duchamp. În fond, Urmuz descoperă că te poţi juca plin de gravitate, compunând un univers artificial cu făpturi de mucava, mişcate nu de resorturi interioare, ci de voinţa mucalită a unui Păpuşar rânjitor faţă de cele lumeşti. Rânjetul sarcastic al Manipulatorului Suprem provine dintr-o suprasaturaţie şi o repulsie faţă de monotonia şi convenţionalismul exprimării tradiționale. Observând potențialul creației literare ca joc, el accentuează impasul şi vidul structurilor lingvistice osificate, dar în același timp le reînnoiește prin permutări infinite. Sensibilitatea sa este de natură rebelă şi novatoare, căutând creaţia prin destructurare şi distrugere. Impasul cel mare consta în formalizarea și retorismul excesiv ale exprimării literare. Un bogat bagaj de clişee şi stereotipii ale imaginilor, reprezentărilor şi genurilor literare circula dintr-o parte într-alta (dintrun tip de text, de pildă, romantic, într-altul, realist), fără nici o modificare în materia expresivităţii literare moştenite. Ce ariditate să citeşti nenumărate pagini care sună la fel, au aceeași fabulă, iar discursul narativ se desfășoară după aceeași schemă! 
Urmuz păstrează, grosso modo, schematismul anumitor specii romaneşti înlăuntrul cărora operează, prin anumite procedee ale deconstruirii şi destructurării convenţiilor, modificări polimorfe şi contradictorii, luându-le în răspăr. Aparenta cuminţenie a supunerii la norma tradițională este dezminţită de contradicţiile interne generate în conţinut. Procedeul fundamental utilizat este cel al amestecului de registre terminologice şi stilistice, marcând nivelul microtextual (lingvistic) ce contaminează macrostructurile textuale ale imaginarului urmuzian (imagini, reprezentări, personaje, situaţii). Lipsa de legătură, de cauzalitate raţională, carteziană, în selecţia sintagmatică a construirii textului pare dominată de hazard, de aleatoriu, fapt ce a determinat apropierea modalităţii sale de creaţie de cea a curentelor avangardiste (dadaismul, constructivismul, integralismul). Dar să nu uităm un lucru esenţial. Iraţionalitatea şi ilogismul textelor sale nu provin dintr-o absență a intenției auctoriale, aşa cum se întâmplă, cel puțin într-o etapă incipientă, cu mişcările experimentale ale avangardei, ci, dimpotrivă. Textele lui Urmuz sunt rodul unei voințe tenace de destructurare și minare intenționată a locurilor comune din literatura tradițională, ținută în acea bibliotecă înfăşurată în cearceafuri ude din apartamentul lui Stamate şi măcinată în stomacul lui Grummer din a cărui băşică îngurgitată de bătrânul Algazy se naşte noua literatură a viitorului. Aceasta este una din cele mai grăitoare imagini pentru poietica urmuziană, care ne-a făcut să ne gândim la legăturile ei, peste timp, cu postmodernismul de mai târziu şi să-l considerăm pe Urmuz un Jarry al literaturii noastre, lăsând la o parte excesiva tuşă pornografică existentă la Alfred (Balotă, 1971: 129). În termenii teoriei literare, scena luptei „mitice” dintre cei doi „uriaşi”, bătrânul Algazy şi mai tânărul Grummer, face trimiteri la retorica deconstrucţiei postmoderniste. Fiindcă totul a fost deja spus şi inventat în literatură, noii generaţii de scriitori nu-i mai rămâne decât să folosească infinite combinaţii şi permutări fragmentare din variate tipuri de scriituri în care conştiinţa creatoare să se ,personalizeze” numai prin preluarea anumitor tipuri de modele scriitoriceşti. La Urmuz tonul este mai accentuat parodic, decât la postmodernişti, iar naraţiunea, fabula (G. Genette), este „desfigurată” de autorul Fuchsiadei, în timp ce la postmodernişti ea este reconstruită şi regăsită, după uscăciunea şi ariditatea experimentelor textualiste care pulverizaseră cu totul epicul din proza literară și nimiciseră instanța narativă clasică. Alte apropieri vizibile sunt cele referitoare la cronologia evenimentelor din biografia personajelor şi la viziunea asupra sfârşitului naraţiunii. Urmuz atacă din plin cronologia desfăşurării ordonate şi logice, în vederea obţinerii uneia dintre sursele umorului său grotesc. „Cronologia” imaginată de el este, fireşte, iraţională şi ilogică, devenind astfel cu putinţă ca: un copil de patru ani, Bufty, să ajungă rivalul în dragoste al tatălui său; pseudo-filosoful Stamate să facă armata la vârsta de un an ca să-şi ajute doi frăţiori mai mici decât el, daţi afară din slujbe din cauza şoldurilor proeminente (Pâlnia şi Stamate); un tânăr bărbat de şaptesprezece ani să-şi serbeze 
nunta de argint la începutul vieţii (Plecarea în străinătate). De la această dezordine temporală, se poate face trecerea, printr-un salt teoretic semnificativ, la derularea ramificată, arborescentă, a cronologiei postmoderniste. In ceea ce priveşte finalurile epice, ele sunt contrariante atât la Urmuz, cât şi la postmodernişti şi urmăresc râcâirea comodităţii cititorului. Primul îşi împinge cititorul să întrevadă un anumit sfârşit, care este tăgăduit în ultima secundă de o radicală şi opusă mişcare de rotaţie, de obicei, în poantă ridicolă, caricaturală. Nu este exclusă, deşi mai rară, o încheiere în registrul retoric înalt, când peripeţiile bufone ale eroului ne-ar fi îndemnat să credem într-un sfârşit asemănător (v. Fuchsiada). La postmodernişti, finalul nu mai este niciodată rotund, simetric (ca la romantici şi realişti, de pildă) şi limpede. Dimpotrivă, el este echivoc, multiplu, deoarece combate ideea că o singură cauză poate avea o singură urmare.

Această problemă a cauzalităţii în narațiune este fundamentală pentru concepţia lui Urmuz. El zeflemiseşte ideea filosofică a lui Aristotel, aceea a existenţei unei „cauze a cauzelor” în devenirea lumii. Dacă atâtea minți luminate s-au străduit, în decursul istoriei umanității, să definească cauzalitatea logic și rațional și n-au izbutit s-o clarifice, înseamnă în mod logic (sic!) că ea nu există, că toţi au alergat după o fantasmă şi că, în cel mai fericit caz, trebuie să acceptăm o multiplicitate de cauze pentru acelaşi efect sau o multiplicitate de efecte pentru aceeaşi cauză. Iată opinia lui Urmuz în rostire directă, din singura parodie a unui potenţial dialog platonian, Puţină metafizică şi astronomie:

[...] cine din noi se mai poate plânge că forţa primordială, cauza cauzelor, nu poate fi niciodată atinsă, descoperită, când toţi se căznesc să apuce de la început, dinapoi, şi nimeni nu s-a încercat să o învăluie, pentru clipa de faţă, să o prindă măcar o dată pe flanc? [...] Deci la ce bun să vrei numai o singură cauză, o forță iniţială care vrem (trebuie) să fie generatoare, când ea însăşi ţine cu atâta încăpăţânare să dea din ea numai multiplicitate; are setea mulţimilor, a încâlcelilor şi a contradicţiei; [...] şi are setea numărului, a distanţelor şi a iuţelilor mari, fără rost şi necesitate [...] (Urmuz, 1996: 61-62).

Aşadar, dată fiind această modernă viziune anticauzală asupra lumii, nu mai e deloc de mirare că universul său ficţional este dominat de absurd şi de iraţional.

$\mathrm{Cu}$ scriitorii literaturii absurdului (E. Ionescu, S. Beckett, Antonin Artaud, S. Mrożek), Urmuz are în comun această neputinţă a personajelor sale de a comunica, atunci când ele îşi manifestă dorinţa de a se produce în faţa unui interlocutor (Cotadi şi Grummer, de pildă). „Limbajul e sursă de neînţelegeri”, spune undeva Antoine de Saint Exupéry. Dar nu numai atât. În termeni moderni, limbajul e una din sursele manifestării înclinaţiilor bătăioase şi a dominaţiei asupra celor mai slabi. Nu mai are nici o importanţă înţelegerea între oameni. În lumea lui Urmuz (ca şi în cea a teatrului absurd al lui Eugen Ionescu; v. piesa Lecţia), actul comunicării este doar un pretext pentru exercitarea violenţei şi agresiunii faţă de semeni. De fapt, contează prea puțin ceea ce ele spun, însă devine esențial faptul de a atrage în apropierea lor naivi ascultători asupra cărora se va exercita plăcerea 
sadică şi tiranică a provocării durerii fizice şi morale. Sterilitatea, neputinţele şi ratările personajelor dau naştere sadismului şi tendinţei de dominare prin violenţă, acest lucru fiind valabil și în plan erotic (Balotă, 1997: 73). Ființe ale nimicului, ale haosului şi rătăcirii, ele au o singură obsesie: să provoace durerea prin care se impun atenţiei celorlalţi, neputând să trăiască altfel decât prin degradarea omenescului.

Ceea ce-1 leagă pe Urmuz de textualiştii de mai târziu este tocmai impresia acută pe care o are cititorul avizat că limbajul începe să funcţioneze după legile sale proprii şi scapă, oarecum, de sub controlul riguros al conştiinţei producătoare. Cum au afirmat o serie de comentatori ai textualiştilor: limbajul se creează pe sine, scriitorul nefiind altceva decât o retortă prin care circulă independent „curenţii" sistemului lingvistic în care se scrie. Acest lucru devine atât de evident tocmai din pricina absenței nivelului figurativ al limbajului, totul având sens propriu (Manolescu, 1983: 26). De aceea ne uimesc unii prefațatori ai paginilor bizare ale lui Urmuz, când susțin tocmai contrariul (Godeanu, 1996: prefață). Țesătura textului urmuzian are, în consecință, o formă fragmentară, secvențială, asemeni unui covoraş oltenesc supraincărcat cu motive şi desene de diferite origini. În ansamblu, rama textului include o incoerenţă a substanţei, ca şi cum ar reprezenta zgomotul şi furia dintr-un imaginar fantastic.

Revenind la estetica urmuziană, după acest succint parcurs printre modernităţile virtuale pe care le cuprind cele zece schiţe ale sale, să ne oprim asupra termenilor centrali din care radiază structura ei, şi anume: criză şi amestec. Primul determină o reformulare radicală a raporturilor creatorului cu arta şi realitatea înconjurătoare, iar cel de-al doilea stabileşte tipul de estetică pe care Urmuz o abordează, ca un pionier explorator al unui pământ încă necunoscut.

Tradiţia literară, împotriva căreia se vor ridica „vocile” tunătoare ale avangardiştilor cu teribila dorinţă (un teribilism provenit din voinţa de diferențiere) de negare totală, alcătuieşte, măcar formal, materialul din care se vor plămădi „urmuzismele”. Criza este un rezultat al fenomenului de suprasaturaţie a scenei literare de la sfârşitul secolului al XIX-lea şi începutul secolului al XX-lea cu modele de scriitură sau tipuri de retorici literare, care, prin utilizarea lor excesivă, au degradat literatura valoroasă în literatură de larg consum. Au fost preluate astfel: din romantism - partea sentimental lacrimogenă şi romanţările biografiei eroilor (cu tot ceea ce implică acest lucru: coincidenţe extraordinare, loviturile de teatru, senzaţionalul şi spectacularul unor aventuri etc); din realism (mai mult de tipul celui balzacian şi mai puţin de genul stendhalian) - pretenţia de mimetism faţă de realitate, descrierile minuţioase şi accentuate ale interioarelor, obiectelor şi vestimentaţiilor; din străvechiul gen al epopeilor antice (nu putem şti dacă Urmuz a citit epopeea lui I. Budai-Deleanu, deşi în mod clar avea solide cunoştinţe de literatură antică) - eroismul muritorilor (un eroism de mucava, desigur) conduşi şi 
ajutaţi, ca în basme, de întruchipări omeneşti ale fatum-ului lor; din romanul de factură psihologică - siguranţa confortabilă a autorului omniscient de a şti ce se petrece în mintea şi sufletul personajelor. La acestea se adaugă acele specii romaneşti, romanul istoric (gen Walter Scott), romanul gotic (Ann Radclife), romanul foiletonistic (Eugène Sue, Ponson du Terrail) şi romanul călătoriilor exotice (gen Marco Polo) care au alunecat, încet-încet, spre ceea ce, astăzi, teoreticienii literaturii numesc paraliteratură sau literatura de larg consum. Părerea noastră este că nu modelele iniţiale ca atare (valoroase şi importante pentru fiecare etapă cultural-literară) au stârnit reacţiile furioase şi revendicative ale moderniştilor, cât mai ales năvala de debuşee născute din repetițiile supăătoare incriminate mai sus. Romantismul, considerat un ferment al anumitor poetici moderniste, și-a avut partea sa de umbră, declamatorie și bombastică.

Prin urmare, Urmuz, conştiinţă creatoare puternică, este cel care provoacă ruptura față de sistemul literar tradiţional din interiorul codurilor stilistice. El ruinează prin caricaturizare şi ridiculizare aceste stiluri, zămislind în acelaşi timp ceva nou. Poziţia sa este aceea a unui pastişor parodic, de geniu, care, lăsând falsa impresie de imitaţie, se distanţează ironic şi satiric de obiectul reproducerii sale. Mimetismul faţă de retoricile tradiţionale şi clasice este unul batjocoritor. De fapt, le maimuţăreşte, subliniindu-le defectele şi viciile. Îngroşarea aceasta, cu intenţii vădit comice şi critice, exilează categoriile estetice luminoase (frumosul, graţiosul, sublimul, agreabilul etc.) şi ne aduce în preajma categoriei tenebroase, paradoxale şi ambigue, a grotescului. Apare, deci, reversul celor dintâi cu întreaga cohortă a urâtului. Şi nu orice fel de urât, ci acela obţinut din îngroşare, unul excesiv al cărui prim reprezentant este hidosul, urmat îndeaproape de monstruos, diform, repulsiv şi scabros. Acestea trebuie, însă, să provoace nu numai respingerea, ci şi sancţionarea şi condamnarea lor prin râs. Aici se face simțită noțiunea de amestec.

Grotescul reprezintă, în consecinţă, acea categorie estetică bivalentă, unind urâtul şi comicul într-o fiinţare contradictorie, polimorfă şi excesivă. El realizează tranziţia între contrarii; ,,ajută” la metamorfozarea unui exces în opusul său, el fiind de fapt elementul catalizator care permite această schimbare, altminteri imposibilă şi de neconceput şi, nu în ultimul rând, reuneşte într-o unică formă elemente incompatibile şi incongruente. Fiecare dintre aceste paliere de acţiune ale grotescului îi compun, în mod paradoxal, identitatea specifică şi includ ideea imanentă de amestec.

\section{LUMEA IMAGINARĂ A LUI URMUZ}

Dintre toate caracteristicile grotescului, textele lui Urmuz ilustrează cel mai bine două dintre ele: polimorfismul şi uniunea contrariilor incompatibile, acea coincidentia oppositorum atât de râvnită de literaţii barocului şi revitalizată de 
scriitorii romantici, după o relativă cădere a sa în desuetudine (Ciorănescu, 1980: 246). Apropierea lui Urmuz de estetica barocului poate să pară stridentă, însă elementul de legătură este constituit de prezenţa grotescului. Nu trebuie să uităm preferinţele declarate ale scriitorilor baroci pentru jocurile de cuvinte (echivocuri), pentru acea formă elementară a contrastului numită discordia concors a oximoronului şi pentru înlocuirea mimetismului faţă de natură cu artificiul. Iar Urmuz este un artifex ludum, care, dând frâu liber imaginaţiei şi inventivităţii sale, plăsmuieşte o meta-lume cu legi proprii. Văditele reminiscenţe ale asemănării cu realitatea (ele există şi nu pot fi ignorate, fapt observat şi de alţi comentatori ai scrierilor lui Urmuz - v. Crohmălniceanu, 1972: 575) sunt utilizate ca materiale distorsionate dinadins pentru a obţine rezultate de un efect cât mai puternic, de ridiculizare şi satirizare. Detestate şi urâte, atât realitatea, cât și tradiţia literară, sunt prelucrate, sub formele lor bine ştiute, şi topite într-un amalgam contrastant şi contradictoriu, tocmai pentru a păstra în mod foarte limpede, capacitatea de referinţă şi de semnificare a textelor sale. S-ar putea crede, ceea ce ar fi total greşit, că, lucrând cu „materiale” anchilozate, închircite de frecventa lor utilizare în acelaşi mod, Urmuz urmăreşte să substituie absenţa lor de sens cu o lipsă de sens şi mai mare, aceea a absurdului. Chiar aşa fiind, absurdul semnifică la rândul lui ceva, din moment dat ce se pot glosa nenumărate pagini pe marginea lui şi i se găsesc trăsături definitorii (v. sintagma lui Nicolae Balotă ,absurditatea absurdului” din Balotă, 1971: 378).

Universul lui Urmuz are evidente asemănări cu anumite picturi sau sculpturi cubiste în care autorii au folosit tehnica colajului. Invazia de materiale disparate, de origini diverse (de la hârtie, pânză, metal, plastic până la lipici, clei, pap, sârmă, destinate să le ţină împreună), este vizibilă cel mai tare în alcătuirea personajelor. $\mathrm{Nu}$ e niciunul care să nu fie polimorf. Legătura cu estetica grotescului se realizează tocmai prin aceste apariţii monstruoase, hibride, sălbatice şi agresive, ce stârnesc mai întâi repulsie şi apoi ilaritate, datorită comportamentului extravagant şi acţiunilor absurde, contrariante. Urâţ̦enia lor, de tipul diformului şi al oribilului, este accentuată (se înţelege: exagerată şi îngroşată) prin trimiterile persistente la sfera vulgarului, scabrosului şi coprologicului. Relaţia cu sfera omenescului (trăsături fizionomice sau corporale, gesturi sau comportamente) este destul de ştearsă, prezenţa caracteristicilor umane îndeplinind doar o funcţie peiorativă, depreciatore, al cărei obiectiv rămâne persiflarea şi batjocorirea lor prin aceste personaje umanoide.

A le considera anti-eroi înseamnă prea mult, este o valorizare nemeritată. Un anti-erou este, de pildă, protagonistul lui Musil din romanul său Un om fără insuşiri, în timp ce personajele urmuziene sunt mai degrabă marionete, păpuşi, măşti groteşti. Structura lor compozită ne fac să ne gândim la acele desene animate în care făpturile erau înfăţişate prin bucăţi de sârmă, aducând cu forma trupului 
omenesc, cu capete, mâini şi picioare de lemn sau, de dată mai recentă, la acele vieţuitoare ambigui din materiale legumicole hibride, care ar fi putut fi orice, depășind net planul referințelor reale și intrând în teritoriul fanteziei dezlănțuite.

Majoritatea păpuşilor lui Urmuz sunt bărbaţi. Atunci când apare vreo figură feminină fugară şi fugitivă, ea este ori o ,inocentă şi decentă pâlnie ruginită” ori o sirenă ,provocatoare şi perversă”. Între reprezentarea obiectuală a ,eternului feminin" şi cea aburos-mitică (inconsistentă, deci, şi la fel de compozită, dacă vizualizăm înfăţişarea sirenei), se perindă „,chipuri” de soţii sau rubedenii de sex femeiesc: soţia „tunsă, legitimă şi credulă” a lui Stamate; una din multele neveste ale lui Algazy cu înfăţişare de mătură (care va executa, într-un exploziv şi neaşteptat final, ca toate de altfel, curăţenia generală, măturându-i pe combatanţi la coş); nepoata rebelă şi belicoasă a lui Gayk; bătrâna soţie ,geloasă, ambiţioasă şi netrebnică" a junelui amator de plecări în străinătate; mătuşa bătrână, putred de bogată, de origine macedoneană și nobilă, viețuind într-o mahala, a lui Cotadi; găina-călugăriță sechestrată de zvăpăiatul spadasin din După furtună; amanta-focă a junelui ,încărcat de glorie şi de ani” (Urmuz, 1996: 37). Pe drept cuvânt s-ar putea face comentarii despre misoginia autorului, după această ocheadă panoramică asupra întruchipărilor feminine din piesele sale epice!

Cât despre cealaltă categorie a eternului feminin, de provenienţă legendarmitică, nu stă nici ea mai bine! Sirenele, nimfele, nereidele din Pâlnia şi Stamate sau din Fuchsiada sunt perverse, dezmăţate şi lubrice, nişte vajnice instigatoare pe căile viciului şi ale desfrâului. Afrodita sau Venera, cântată secole de-a rândul de poeţi pentru frumuseţe şi inaccesibilitate, este terfelită şi demitizată în Fuchsiada sub chipul unei banale târfe de lux, doritoare să se însoţească în aşternut cu insignifiantul, dar genialul muzician, Fuchs, pentru a da naştere unei seminţii de urmaşi supradotaţi. Ratarea misiunii sale de procreare a unor „copii divini” (mai terestru spus: impotenţa sexuală a muzicianului) este pedepsită, după alungarea din Olimp, raiul zeilor, cu „obligaţia de a distruge snobismul şi laşitatea cugetării în artă de pe meleagurile pământene" (Urmuz, 1995: 58). Lucru de care infimul şi naivul Fuchs se dovedeşte la fel de incapabil. Maculat fiind după experienţa erotică ratată în faţa zeiţei, îşi va dori doar să se reabiliteze în ochii ei şi să aibă astfel o a doua şansă de a-şi dovedi bărbăţia, uitându-şi cu totul misiunea şi condiţia de artistmuzician. Ce eroare şi inconsecvenţă! El ratează actul creaţiei de două ori: ca om şi ca artist. Haosul în care este azvârlit apoi nu-i decât o cuvenită pedeapsă pentru rătăcirile sale. Nu-i mai rămâne apoi decât să se scufunde în neantul pur, ceea ce se şi întâmplă, după ce Atena, îndurătoare, îl salvează de teribila sarcină a înnoirii artei muzicale (care i se pare lui Fuchs chiar mai dificilă decât aceea de a procrea copii). Toate aceste peripeţii fuchsiene ne servesc în a demonstra că singura apariţie feminină marcată pozitiv este a efemerei Pallas-Atena. În termeni urmuzieni, am putea trage concluzia că femei înţelepte nu există! Ele sunt doar proaste, 
insignifiante, geloase, invidioase, ambiţioase în sens rău, meschine, neînţelegătoare, brutale. Acesta constituie totodată şi pretextul pentru a trece la descrierea relaţiilor erotice din imaginarul lui Urmuz.

Modul în care se manifestă aceste relaţii nu poate fi altul decât deviant, anormal şi pervers, dată fiind pulverizarea misogină a eternului feminin. Peste relaţii nefireşti domnesc violenţa şi silnicia, iar partenerii sunt agresivi și încearcă să se impună cu anasâna, ca să-şi dovedească superioritatea, inexistentă în fond. Cum s-a remarcat deja, „erosul urmuzian înseamnă seducţie şi corupţie” (Balotă, 1997: 70). Dovada cea mai clară în acest sens este chiar destinul lui Fuchs. Îmbiat cu plăcerile carnale, pe care le ignoră cu o autentică şi copilărească inocenţă, el nu mai e în stare să-şi reia castele ocupaţii de compozitor, dimpotrivă le abandonează în favoarea unei virtuale întoarceri „triumfale” în patul Zeiţei Amăgitoare. Există, aşadar, un eros infernal, în care aşa-zisa relaţie de cuplu (introdusă de majoritatea titlurilor, patru din zece!, date de către Urmuz: Pâlnia şi Stamate, Ismail şi Turnavitu, Cotadi şi Dragomir, Algazy şi Grummer) nu este una partenerială, cum am fi înclinaţi să credem datorită egalităţii sintactice stabilite de conjuncţia copulativă, ci una de subordonare. Unul tiranizează, iar celălalt, din imediata lui proximitate, este victimă. Unul comandă sau ordonă, celălalt slujeşte şi execută orbeşte. Există destule variante ale erosului deviant pe care le întâlnim în textele lui Urmuz: zoofilia (Ismail creşte viezuri pentru a-i necinsti; în alt loc gelozia unei consoarte este stârnită de relaţia extraconjugală a soţului cu o focă), pedofilia şi incestul (unchiul şi nepoata cu tendinţe belicoase din Emil Gayk), homosexualismul (Cotadi şi Dragomir), fetişismul (,iubirea” lui Stamate pentru pâlnia adusă de nimfe). În afară de aceasta, sadomasochismul este la mare preț printre făpturile acestea tarate, contaminate de „un rău primordial” (Balotă, 1997: 75), fiindcă nu-i iubesc decât pe cei cărora le provoacă dureri fizice şi psihice. Prin urmare, nu există nici o valorizare pozitivă a erosului, a iubirii omeneşti, şi nici vorbă de amor sacru, cel îndreptat spre fiinţe transcendente, cu conotaţii mistice, idealizatore şi religioase. Sacră sau nu, iubirea este profanată şi distrusă (Balotă, 1997: 69). În acest caz, se justifică cel mai bine aserţiunea comună: „Dacă dragoste nu e, nimic nu e”.

De aceea, singurele reacţii posibile, ca urmare a sterilităţii simţirii, sunt gelozia, răzbunarea, ranchiuna vindicativă, pedepsele corporale şi posesiunea forţată care urmăresc impunerea voinţei personale celuilalt şi împingerea celui slab spre moarte (anihilare, sinucidere). Stamate, dezamăgit de amantă (pâlnie) se răzbună pe nevastă claustrând-o într-un sac, după o prealabilă intoxicare a ei cu vopsea. Turnavitu, ,fire sensibilă" (Urmuz, 1996: 32), umilit de concedierea nedreaptă din postul de supraveghetor de viezuri în crescătoria lui Ismail, se sinucide „după ce avu însă mai întâi grijă să îşi scoată cei patru dinţi canini din gură” (Urmuz, 1996: 32), adică săşi scoată proteza dentară. Gayk, singurul civil purtător de armă, îşi agresează nepoata cu speranţa de a o intimida şi a o face să renunţe la revendicările sale: 
„a cerut iubitului său unchi să o elibereze din pension şi să fie acasă la câmp" (Urmuz, 1996: 34). Netrebnica soţie a junelui amator de călătorii în străinătate, ca să se despăgubească pentru afrontul adus de acesta prin refuz, îşi leagă consortul cu o frânghie de „umerii obrajilor” şi-l târăşte prin oraş până la „marginea corăbiei” (Urmuz, 1996: 37). „Viteazul” spadasin din După furtună o răpeşte pe găinacălugăriţă (precum au fost odinioară răpite Sabinele), pe cea care-1 întâmpinase sfioasă, cucernică şi caritabilă în poarta mănăstirii, vârând-o sub gheroc şi obligândo să întemeieze împreună o familie. Nici după moarte, cel slab şi hăituit în timpul vieţii nu este lăsat în pace. Rapacitatea şi meschinăria lui Cotadi faţă de amicul său, Dragomir, est fără egal: „spre a putea acapara pentru totdeauna sursa eternă a bogăţiilor din capul lui Dragomir, a lăsat prin testament ca să fie îngropat în aceeaşi groapă cu acesta" (Urmuz, 1996: 42). Lipsa de respect faţă de viaţă se extinde şi asupra morţii, iar cei care nu ştiu să trăiască, nu ştiu nici să moară.

$\mathrm{N}$-am dorit să relevăm, mai sus, un anost pomelnic de legături vicioase şi nefireşti în plan erotic, doar de dragul de a le exhiba fără rost. Pe de o parte acestea ţin de „erosul hidos” (după expresia foarte potrivită a lui N. Balotă: inşii aceştia trăiesc în „bolgiile erosului” - v. Balotă, 1997: 64-65), care desemnează o lume respingătoare, bolnavă, devitalizată, dezumanizată şi în descompunere; pe de altă parte lista de aberaţii erotice enumerată fixează în atenţia noastră acea latură a transgresării regnurilor, a amestecului dintre ele (mecanic, animalier, vegetal, umanoid). Intenţia noastră este, deci, de a arăta că urâtul excesiv şi polimorfismul îşi înfig şi în acest „teritoriu” tentaculele acaparatoare. De fapt, maladiile erosului denotă dezagregarea vieţii.

Acestei serii sexuale infamante i se alătură acte ale fiziologicului elementar, precum nutriţia şi coprologicul, peste care se lasă aceeaşi atmosferă putridă şi scabroasă. Aşa cum M. Bahtin, vorbind despre cronotopul rabelaisian (Bahtin, 1982: 394), consideră grotescul ca rezultat clar al intersectării şi asocierii diferitelor serii de toposuri (mâncarea, băutura, sexualitatea, coprologicul, aspecte anatomice şi fiziologice), nu putem să nu observăm că și la Urmuz apar astfel de intersectări de serii toposuri. Elementele pornografice şi triviale se manifestă și la Urmuz în descrierile batjocoritor-satirice ale creaturilor sale. Hrana lor nu este în strictă dependenţă de materialele care intră în componența hibridă a acestor făpturi, cu toate că s-ar putea crede contrariul. Ele mănâncă orice din ceea ce n-ar putea mânca, sub nici o formă, un om, ca şi cum separarea de sfera larvar-amorfă cărora le aparţin începe cu un acest act fiziologic simplu, cel al nutriţiei. Preferinţele lor se îndreaptă, totuşi, spre resurse alimentare dure (rumegătură de lemne, arşice, bobine de arnici, bani, cârpe), vegetale (semințe de cânepă, alune, scoruşe), carnivorerespingătoare (viezuri, picioruşe de caracatiţă, ouă de furnici, guşe de păsări, băşici ale udului, insecte moarte) şi, rareori, gătite (pâine, lipii). Ele confundă sexualitatea cu nutriţia, substituind-o pe una prin cealaltă. Fuchs se hrăneşte, de pildă, cu frunza 
de viţă ce-i ţine loc, ca la statuile antice, de organe genitale şi care-i creşte la loc după fiecare consumaţie de acest gen. Cei mai mulţi suferă de antropofagii sinistre şi macabre. Gayk îşi ciuguleşte nepoata, adică îi ciunteşte din „carne”, de fiecare dată când se supără. Ismail „cultivă” într-o pepinieră proprie viezuri pe care, mai întâi, îi siluieşte şi, pe urmă, îi mănâncă, în timpul nopţii, cruzi şi vii, după ce le-a rupt urechile şi a stors pe ei puţină lămâie. Satanic comportament! Algazy şi Grummer se consumă reciproc, în vestita scenă a confruntării „eroice” dintre ei, până când nu mai rămâne nimic din aşa-zisa lor „corporalitate”. Aluziile parodice trimit, desigur, la cunoaş̧erea de sine din simbolul legendar al şarpelui care-şi muşcă coada din literatura universală, Quetzalcoatl, sau la imaginea barbiană a lui Nastratin Hogea care se hrăneşte cu propriul lui trup, încovrigat peste el-însuşi. Aici, însă, nu este consumat ego-ul propriu, ci ego-ul celuilalt, de parcă ni s-ar sugera că dorința de a ne cunoaşte semenul este destructivă atât pentru subiectul cunoscător, cât şi pentru obiectul-țintă al cunoaşterii. Lumea, semenii şi conştiinţa noastră nu merită, aşadar, osteneala să fie cunoscute.

Raporturile de forţă, dominare şi violenţă contaminează şi celelalte zone ale existenţei acestor marionete, în special cea socială, ca să nu mai vorbim de afectivitate, mai precis de aşa-zisa prietenie dintre protagonişti. Ele converg spre accentuarea uscăciunii, atrofiei şi nimicului sufletesc. De aceea, din portretizarea „concisă şi esenţializată” (Manolescu, 1983: 27) a personajelor lipsesc aproape cu desăvârşire analizele morale şi psihologice. Descrierile acestor fiinţe care şi-au pierdut interioritatea (conştiinţa ego-ului, minte şi suflet) şi omenescul, conţin combinări de notaţii divergente şi de origini diferite. Astfel, caracteristici pozitive sunt asociate, contrariant şi rizibil, cu cele dezgustătoare. În toate cazurile, atunci când apare o trăsătură morală, fizică sau comportamentală pozitivă, imediat ea este contracarată de una negativă, scârboasă, ca şi cum autorul s-ar teme să atragă asupra creaturilor sale o simpatie nemeritată. Evident, în acest mod, potenţiala simpatie este întotdeauna retrasă. Referirile la trăsături fizice umane sunt completate (după o prealabilă ,„îfierare” a lor cu tuşe terminologice dezagreabile, de-a dreptul greţoase) de componenta vestimentară (foarte importantă pentru Urmuz) şi de elemente de provenienţă mecanică, zoologică, abstractă (figuri geometrice) sau, pur şi simplu, obiectuală. În şirul enumerativ caracterizator se ivesc „rupturi” terminologice care provoacă iniţial stupefacţia, apoi greaţa şi, în final, amuzamentul.

Câteva exemplificări ne vor susţine, cu vârf şi îndesat, afirmaţiile. Pseudofilosoful Stamate este „om demn [valorizare morală pozitivă], unsuros [apreciere fizică respingătoare] şi de formă aproape eliptică [sugestie caricatural-amuzantă referitoare la înfăţişarea generală]” (Urmuz, 1996: 25). Bufty: „copil, gras [însuşire depreciativă], blazat [epitet contrariant] şi în etate de patru ani [referinţă batjocoritoare]” (Urmuz, 1996: 25). Soţia lui Stamate: „legitimă [precizare 
superfluă, pleonastică şi comică, făcută cu intenţia de a induce perplexitate, căci termenul „soţie” cuprinde ideea de „legitimitate”] şi tunsă” [aluzie persiflatoare la viaţa de deţinut încarcerat al unor neveste]. Ismail este format din „ochi, favoriţi şi rochie de gală, făcută din stofă de macat de pat cu flori mari, cărămizii” (Urmuz, 1996: 30-31), unde asocierea favoriţilor (element de virilitate) cu rochia (element feminin) marchează, jignitor, individualitatea homosexuală a ipochimenului. Turnavitu este „un simplu ventilator de cafenea” care ajunge, pe căi oculte, „ventilator de stat" (Urmuz, 1996: 32) şi, anual, ia formă de bidon [infuzia de sarcasm trimite la parvenitismul politic şi la lipsa de valoare a politicienilor, ce continuă să taie frunză la câini la guvernare, după ce au fost nişte amărâţi de pierdevară prin bistrouri şi cafenele]. Trăsăturile fizice păsăreşti (guşă, cioc) şi comportamentul adecvat acestei origini sunt foarte frecvente la personajele urmuziene: Emil Gayk este individualizat printr-un „cioc de lemn aromatic”; Cotadi are, printre altele, o gușă cu pieliță fină; Grummer posedă și el un cioc; iar zăbăucul „spadasin” din După furtună are un comportament păsăresc: se suie în copac, se distrează sărind din cracă-n cracă şi, amuzament final, se găinăţează asupra întregului univers; teribilistul amator de voiajuri în ţări străine ne înfăţişează, fără legătură cu referințe anterioare ,un cioc mătăsos, plutind liber şi nesupărat de nimeni pe apa rece şi proaspătă a pârâiaşului cristalin" (Urmuz, 1996: 37) şi are obiceiuri alimentare de găină. Gayk mai este înzestrat cu un obiect de vestimentaţie extravagant şi obscen: „o perdeluţă cu brizbrizuri, una în faţa şi alta în spate, care se pot da uşor în lături...” (Urmuz, 1996: 33). Cotadi este „scurt şi pântecos [nimic în neregulă până aici, fiindcă avem de-a face cu o fizionomie clasică, acceptată], cu musculatura proeminentă [deja suntem surprinşi de ilogismul descrierii: cum ar putea să se vadă musculatura la o persoană grasă?] şi cu picioarele îndoite de două ori în afară şi o dată înăuntru [saltul spre monstruozitate este realizat de acea funcţionare independentă şi mucalită a limbajului, menţionată şi de alţi critici ai lui Urmuz]” şi are „un păr negru ca pana corbului [clişeu descriptiv tradiţional] plin de mătreață [caricaturizarea burlescă a stereotipiei fizice]", iar, în plus, include în înfăţişarea sa „muchia unui capac de pian pe care-1 are înşurupat la spate, deasupra feselor [localizare trivială şi voit dezagreabilă]", servindu-i de urinar. Asemeni lui Cotadi, Grummer, ,fire închisă şi temperament bilios” (Urmuz, 1996: 44), este şi el posesorul unei ciudate construcţii dorsale ,o băşică cenuşie de cauciuc, înşurupată la spate, puţin deasupra feselor" (Urmuz, 1996: 45).

După cum se poate constata din analiza textului, eclectismul este modalitatea fundamentală de plăsmuire a creaturilor urmuziene. Din această perspectivă, ni se pare improprie afirmaţia conform căreia personajele lui Urmuz sunt mecanomorfe ori zoomorfe. Formula de definire a lor este cu mult mai complexă, deoarece câte o componentă disparată (obiectuală, zoologică sau animalieră, mecanică, umanoidă, vegetală), intră în fiecare dintre aceste personaje. Cu mult mai potrivită, ni se pare 
calificarea lor drept marionete sau măşti. Amândouă fac trimitere la lipsa de conţinut, adică de suflet, de conştiinţă şi, în cele din urmă, de viaţă atât de tipică pentru ele. De fapt, sunt nişte plăsmuiri coşmareşti şi infernale care îngrozesc şi terorizează, dar, în acelaşi timp, din pricina laturii derizorii, caricaturale, bufoneşti, vulgar-pornografică, induc comicul în contemplator, mai precis un anumit gen de comic, mai grosolan, datorat ridicolului, bufonadelor, farsei, burlescului. Oribilul şi înspăimântătorul, degajat de ele, sunt topite, anihilate, de apariţia râsului. Or, grotescul îşi face simţită prezenţa tocmai în această situaţie tranzitorie şi conciliatoare între incompatibilităţi estetice.

\section{BIBLIOGRAFIE}

Bahtin, M. (1982): Cronotopul rabelaisian. In: Probleme de literatură și estetică. București: Univers.

BALOTĂ, N. (1971): Lupta cu absurdul. București: Univers.

BALOTĂ, N. (1997): Urmuz. Timișoara: Hestia.

CIORĂNESCU, Al. (1980): Barocul sau descoperirea dramei. Cluj-Napoca: Dacia.

CROHMĂLNICEANU, Ov. S. (1972): Literatura română între cele două războaie mondiale. București: Minerva.

CROHMĂLNICEANU, Ov. S. (1978): Literatura română și expresionismul. București: Minerva.

Godeanu, Gh., (1996): Prefața. In: Urmuz. Pagini bizare. București: Pantheon.

GRIGORESCU, D. (1980): O artă germanică; În literatura română. In: Istoria unei generații pierdute: expresioniștii. București: Editura Eminescu.

MANOLESCu, N. (1983): Arca lui Noe (eseu despre romanul românesc modern). Vol. 3. București: Minerva.

Micu, D. (1985): Modernismul românesc. Vol. II. De la Arghezi la suprarealism. București: Minerva.

URMuZ (1996): Pagini bizare. București: Pantheon. 